\title{
Transposon Tn917PF1 mutagenesis in Bacillus licheniformis
}

\author{
Zoltán Prágai, ${ }^{1}$ Son Lam Phan Trân, ${ }^{1}$ Tibor Nagy, ${ }^{3}$ László Fülöp, ${ }^{2}$ András \\ Holczinger ${ }^{1}$ and Tibor Sík ${ }^{1}$
}

\author{
Author for correspondence: Zoltán Prágai. Tel: +36 28310 200. Fax: + 3628310 804. e-mail: \\ pz@rkt.gau.hu
}

1,2 Department of Biotechnology' and Department of Biochemistry2, Gödöllố University of Agricultural Sciences, Gödölló, H-2103, Hungary

3 Institute of Molecular Genetics, Agricultural Biotechnology Center, Gödölló, H-2101, Hungary

\begin{abstract}
The plasmid pTnPF1 containing the transposon Tn917PF1 was introduced into the protoplasts of two Bacillus licheniformis strains in the presence of polyethylene glycol. Transpositions were produced at high temperature which inhibited plasmid replication and kanamycin was used for selection. Transposon Tn917PF1 was inserted randomly into the bacterial chromosome, producing different auxotrophic, prophage BLF and bacitracin-non-producing mutants. The auxotrophic mutant phenotypes were characterized by the Holliday-test and some mutations by hybridization with a transposon DNA probe. Insertions for the entire chromosome or for the prophage genophore were found at random, but preferred target sites were detected within limited regions, like the bacitracin synthetase or sulphate reductase genes. The partial physical map of the chromosomal region of bacitracin synthetase was constructed based on the hybridization patterns of insertion mutants.
\end{abstract}

Keywords: Bacillus licheniformis, transposon mutagenesis, auxotroph, prophage mutant, bacitracin synthetase

\section{INTRODUCTION}

Transposons are useful tools for genetic analysis. In bacilli, the enterococcal transposon $\mathrm{Tn} 917$ is the most frequently used for transposition mutagenesis (Youngman et al., 1983; Bohall \& Vary, 1986; Hartley \& Paddon, 1986; Wati et al., 1990). This transposon and its developed versatile derivatives are suitable for insertional mutagenesis (Vandeyar \& Zahler, 1986; Sandman et al., 1987), rapid cloning (Youngman et al., 1984), the construction of transcriptional gene fusions (Perkins \& Youngman, 1986; Zuberi et al., 1990; Youngman, 1990) and the characterization of genes which are over-expressed (Zagorec \& Steinmetz, 1991).

The peptide antibiotic bacitracin $(\mathrm{Bt})$-producing Bacillus licheniformis strain 19 carries three temperate bacteriophages: LP52 (Doskočil et al., 1986), DLP10716 (Thorne \& Kowalski, 1976) and BLF (Holczinger, 1986) integrated as prophages into the chromosome. Having a natural erythromycin $(\mathrm{Em})$ resistance determinant on the chromosome, the erm gene of $\operatorname{Tn} 917$ is non-selectable in this strain. Therefore the Tn917PF1 derivative, carrying

Abbreviations: $\mathrm{Bt}$, bacitracin; $\mathrm{Cm}$, chloramphenicol; Em, erythromycin; EtBr, ethidium bromide; $\mathrm{Km}$, kanamycin. an additional kanamycin $(\mathrm{Km})$ resistance gene for selection, was used. Since the promoter of this $a p h A^{\prime}$ gene is strong and outward-directed, the Tn917PF 1 can also be used for the isolation and characterization of mutants with certain gene over-expression in B. subtilis (Zagorec \& Steinmetz, 1991).

Transposon mutagenesis using Tn917PF1 is reported here for two $B$. licheniformis strains, to obtain different insertion mutants. Auxotrophic, Bt synthetase and BLF prophage mutants were selected and characterized by the Holliday-test, antibiotic or phage production. Insertion sites were determined by hybridization with the transposon DNA.

\section{METHODS}

Bacterial strains and plasmids. B. licheniformis 19 (our laboratory) is an industrial Bt-producing strain and is resistant to Em. Three temperate bacteriophages (LP52; DLP10716 and $\mathrm{BLF}$ ) are integrated in its chromosome. B. licheniformis ATCC 9800 ( $\equiv$ ATCC 9789) (OKI, Budapest, Hungary) is a Bt-nonproducer and is sensitive to phage BLF. Both strains are prototrophic. Micrococcus flavus (M. luteus) ATCC 10240 (OKI, Budapest, Hungary) was used to test Bt production. Plasmid pTnPF1 (Zagorec \& Steinmetz, 1991) contains the $\mathrm{Km}$ resistance gene $a p h A^{\prime}$ from $\operatorname{Tn} 1545$ which was inserted into the transposon $\operatorname{Tn} 917$ without the putative terminator. The plasmid 
had a super-thermosensitive replication origin and a chloramphenicol $(\mathrm{Cm})$ resistance marker outside the transposon sequence. The plasmid donor was B. subtilis GM479.

Media. For the transformation of B. licheniformis protoplasts, media as described by Prágai et al. (1994), YTA media described by Sík et al. (1980) and BMM minimal medium described by Hanlon \& Hodges (1981) were used.

Determination of Tn917PF1 transposition frequency. The frequency of transposition was determined essentially as described by Youngman (1987). B. licbeniformis carrying pTnPF1 was grown in Y'A broth containing $20 \mu \mathrm{g} \mathrm{Cm} \mathrm{ml}^{-1}$ and $10 \mu \mathrm{g}$ $\mathrm{Km} \mathrm{m}^{-1}$ at $30^{\circ} \mathrm{C}$ until the mid-exponential phase. Dilutions were plated in two series on YTA plates supplemented with $\mathrm{Km}$ $\left(10 \mu \mathrm{g} \mathrm{ml}^{-1}\right)$ or $\mathrm{Km}$ and $\mathrm{Em}\left(10\right.$ and $\left.1 \mu \mathrm{g} \mathrm{ml}^{-1}\right)$ and incubated at either permissive $\left(30^{\circ} \mathrm{C}\right)$ or non-permissive $\left(50^{\circ} \mathrm{C}\right)$ temperatures for plasmid replication. The transposition frequency was expressed as the ratio of c.f.u. at $50^{\circ} \mathrm{C}$ and $30^{\circ} \mathrm{C}$.

Selection for Tn917PF1-generated chromosomal insertions. A single colony of $B$. licheniformis carrying PTnPF1 was grown in YTA broth containing $20 \mu \mathrm{g} \mathrm{Cm} \mathrm{ml}^{-1}$ and $10 \mu \mathrm{g} \mathrm{Km} \mathrm{ml}^{-1}$ at $30{ }^{\circ} \mathrm{C}$ overnight $(14-16 \mathrm{~h})$. The culture was diluted 1000 -fold into $5 \mathrm{ml}$ of $50^{\circ} \mathrm{C}$ YTA broth containing $10 \mu \mathrm{g} \mathrm{Km} \mathrm{ml}^{-1}$ and grown until the late exponential phase $(10-12 \mathrm{~h})$. The culture was then diluted and plated on YTA agar medium containing $10 \mu \mathrm{g} \mathrm{Km} \mathrm{ml}{ }^{-1}$ and incubated at $50^{\circ} \mathrm{C}$ overnight $(14-16 \mathrm{~h})$. After incubation, colonies were screened for $\mathrm{Cm}$ sensitivity on YTA agar medium containing $10 \mu \mathrm{g} \mathrm{Km} \mathrm{ml} \mathrm{Km}^{-1}$ and $20 \mu \mathrm{g}$ $\mathrm{Cm} \mathrm{m}^{-1}$. Km-resistant and $\mathrm{Cm}$-sensitive colonies were candidates to carry $\operatorname{Tn} 917$ PF 1 insertions and to eliminate the vector. Plasmid elimination was confirmed in 100 samples by the quicktest method (Prágai et al., 1994).

Isolation and identification of auxotrophs. Colonies of $B$. licheniformis carrying $\mathrm{Tn} 917 \mathrm{PF} 1$ insertions were transferred to BMM minimal medium and auxotrophs were detected as nongrowing. Auxotrophic mutants were characterized by growth on BMM minimal medium supplemented with different combinations of amino acids, vitamins, purines and pyrimidines (Holliday, 1956) and then verified.

Isolation of Tn917PF1 insertions into prophage BLF. $B$. licheniformis $19 \mathrm{Tn} 917 \mathrm{PF} 1$ insertion mutants were tested on the BLF-sensitive strain ATCC 9800 for phage production. Mutants which did not produce a lysis halo around the colony on the lawn were selected.

Isolation of Bt-non-producing mutants. B. licheniformis 19 Tn917PF1 insertion mutants were tested on a $M$. flavus lawn for $\mathrm{Bt}$ production. Those having no inhibition zone around the colony after incubation for $24 \mathrm{~h}$ at $37^{\circ} \mathrm{C}$ were selected.

DNA isolation. Plasmid pTnPF1 DNA was isolated from $B$. subtilis GM479 by a large-scale plasmid purification method using alkaline lysis and $\mathrm{CsCl}-\mathrm{EtBr}$ centrifugation (Bron, 1990). Total DNA was extracted from the strains and insertion mutants as described by Bron (1990).

Restriction endonuclease digestion. The enzymes were purchased from Stratagene and used according to the manufacturer's specifications.

DNA-DNA hybridization. Endonuclease-treated DNAs were separated by agarose gel electrophoresis $(0.7 \%)$, denatured and blotted onto nitrocellulose as described by Perbal (1988). Denatured plasmid pTnPF1 or BLF phage DNA was radiolabelled with $\left[{ }^{32} \mathrm{P}\right] \mathrm{dCTP}$ (Amersham) using the ${ }^{\mathrm{T} 7}$ QuickPrime Kit (Pharmacia) according to the manufacturer's specifications.
Prehybridization, hybridization and detection were as described by Sambrook et al. (1989).

\section{RESULTS}

\section{Tn917PF1-generated chromosomal insertions}

Plasmid pTnPF1 carrying transposon Tn917PF1 was isolated from $B$. subtilis GM479, and introduced into $B$. licheniformis 19 and A TCC 9800 protoplasts in the presence of $30 \%(\mathrm{w} / \mathrm{v})$ polyethylene glycol 6000 . Transformants were selected with $\mathrm{Cm}$ and $\mathrm{Km}$ and their plasmid content was confirmed by the quick-test method (Prágai et al., 1994).

The Tn917PF1 average transposition frequency, determined in three independent experiments (selection with $\mathrm{Km}$ ), was $8.6 \times 10^{-4}$ and $1.2 \times 10^{-3}$ in B. licheniformis 19 and ATCC 9800, respectively. When both $\mathrm{Km}$ and Em were used for selection, the corresponding frequencies were $7 \cdot 2 \times 10^{-4}$ and $1 \cdot 1 \times 10^{-3}$, respectively. The close similarity of these results indicated that Em did not induce transposition in B. licheniformis and therefore was omitted in further experiments.

The Tn917PF1-generated insertion mutants of two $B$. licheniformis strains were selected with $\mathrm{Km}$ at $50{ }^{\circ} \mathrm{C}$. To obtain transposition results (Table 1) as accurately as possible, 190-200 colonies were tested from many independent experiments. In this way, the distorting effect of a possible 'jackpot' event of early transposition might be decreased. After heat-treatment at $50^{\circ} \mathrm{C}, 99 \%$ of the colonies became $\mathrm{Cm}$-sensitive, proving effective plasmid elimination and showing that all $\mathrm{Km}$-resistant colonies resulted from the transposition (the frequencies of spontaneous chromosomal Km-resistant mutations in $B$. licheniformis 19 and ATCC 9800 were $1 \times 10^{-7}-3 \times 10^{-7}$ ).

To determine whether random or site-specific Tn917PF1 insertions occurred in the chromosome of $B$. licheniformis 19, 13 independently isolated insertion mutants were examined by hybridization with the transposon probe. Since Bam HI cleaves Tn917PF1 to a 1.6 and $5.0 \mathrm{~kb}$ fragment, two hybridizing bands should have resulted from the BamHI-digested chromosomal DNA of the

Table 1. The results of transposon Tn917PF1 mutagenesis for two $B$. licheniformis strains

\begin{tabular}{|lcc|}
\hline & ATCC 9800 & 19 \\
\hline No. of independent experiments & 30 & 29 \\
No. of the tested colonies & 5860 & 5620 \\
Km-resistant colonies & $100 \%$ & $100 \%$ \\
Cm-sensitive colonies & $98 \cdot 8 \%$ & $99 \cdot 3 \%$ \\
Auxotrophic colonies & $1.0 \%$ & $0 \cdot 7 \%$ \\
Colonies with defective BLF & - & $0.35 \% *$ \\
prophage & & \\
Bt-non-producing colonies & - & $0 \cdot 6 \% *$ \\
\hline
\end{tabular}

*Only 2000 of the 5620 colonies were tested for phage BLF or $\mathrm{Bt}$ production as described in Methods. 


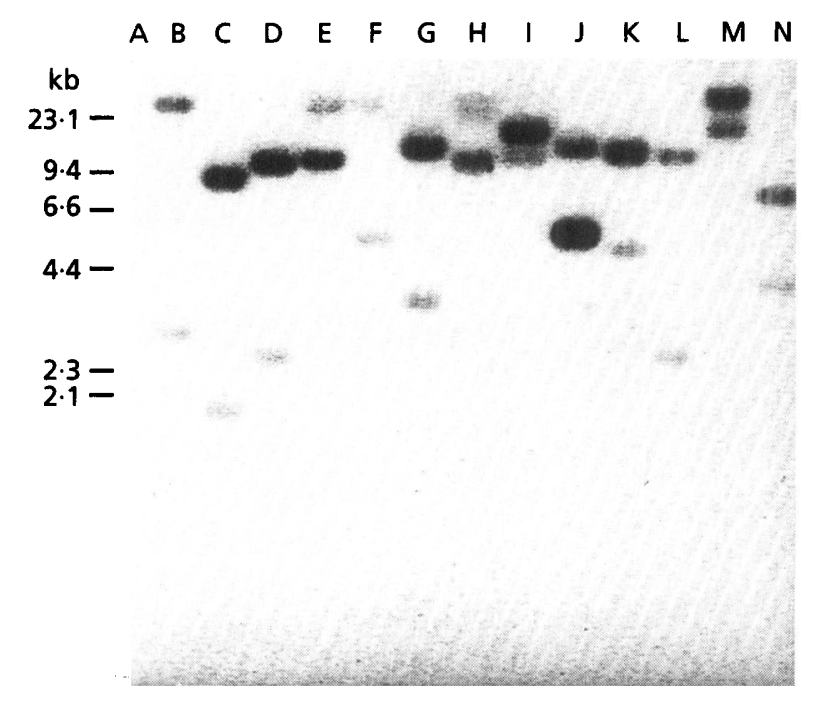

Fig. 1. Southern hybridization of BamHl-digested $B$. licheniformis 19 chromosomal DNA samples containing Tn917PF1 insertions with ${ }^{32} \mathrm{P}$-labelled pTnPF1 DNA probe. The molecular mass marker was Hindlll-digested $\lambda$ DNA. Lanes: $A$, wild-type B. licheniformis 19; B-N, B. licheniformis 19 Tn917PF1 insertion mutants.

Table 2. Identification of $B$. licheniformis auxotrophs by the Holliday-test

Fifty-eight and 39 auxotrophic mutants of B. licheniformis ATCC 9800 and B. licheniformis 19 , respectively, were identified.

\begin{tabular}{|lcc|}
\hline Requirements & $\begin{array}{c}\text { Auxotrophs (\%) } \\
\text { of strain: }\end{array}$ \\
\cline { 2 - 3 } & ATCC 9800 & $\mathbf{1 9}$ \\
\hline Arginine & $5 \cdot 2$ & $2 \cdot 6$ \\
Arginine or ornithine & $6 \cdot 9$ & $7 \cdot 7$ \\
Aspartic acid & - & $5 \cdot 1$ \\
Cysteine & - & $5 \cdot 1$ \\
Cysteine or thiosulphate & & \\
or methionine & $24 \cdot 1$ & - \\
Histidine & $1 \cdot 7$ & - \\
Isoleucine & $6 \cdot 9$ & - \\
Methionine & $3 \cdot 5$ & $10 \cdot 3$ \\
Nicotinic acid & - & $2 \cdot 6$ \\
Proline & - & $7 \cdot 7$ \\
Riboflavin & - & $5 \cdot 1$ \\
Serine & $3 \cdot 5$ & $10 \cdot 3$ \\
Thiamine & $10 \cdot 3$ & $15 \cdot 3$ \\
Threonine & $3 \cdot 5$ & - \\
Tryptophan & $12 \cdot 0$ & $5 \cdot 1$ \\
Uracil & $1 \cdot 7$ & $12 \cdot 8$ \\
Undetermined & $20 \cdot 7$ & $10 \cdot 3$ \\
\hline
\end{tabular}

mutants. As shown in Fig. 1, only two hybridizing bands of different sizes were detected in every lane. This indicates a single copy of Tn917PF1 in each chromosome. Ap- parently, different sites were used by the transposon in different chromosomes, confirming random insertion.

\section{Isolation and characterization of auxotrophic mutants}

A total of $58(1 \%)$ auxotrophic mutants were detected from B. licheniformis ATCC 9800 and $39(0.7 \%)$ from strain 19 (Table 1). For strain ATCC 9800, 11 different classes, and for strain 19, 12 different classes of nutritional requirements and one unspecified class could be distinguished (Table 2).

To determine reversion frequencies, a $B$. licheniformis ATCC 9800 sulphate reductase mutant and a $B$. licheniformis 19 thiamine auxotroph were grown for 20 generations in YTA broth without $\mathrm{Km}$. The cells were then washed with sterile distilled water and the dilutions plated on YTA agar and BMM minimal medium. No prototrophic revertants were observed among $1.5 \times 10^{7}$ and $2.5 \times 10^{7}$ c.f.u., respectively, so the reversion rates were less than $10^{-9}$ per generation.

To examine whether site-specific or random insertions occurred within the classes of selected auxotrophic mutants, DNAs of 14 B. licheniformis ATCC 9800 sulphate reductase mutants (requiring cysteine, thiosulphate or methionine) were single- and double-digested with EcoRI and BamHI, the fragments separated by agarose gel electrophoresis and hybridized with radiolabelled transposon DNA (Fig. 2). One hybridizing fragment was expected after EcoRI digestion and two after BamHI single and EcoRI + Bam HI double digestion (no EcoRI sites and one Bam HI site exist within Tn917PF1). Twelve insertions, resulting in the same hybridization pattern, seemed to be identical. Since Southern hybridization can only distinguish insertions 100 bp apart, DNA sequencing of target sites will be needed to conclude that the 12 mutants have the same insertions. Two mutants had different patterns. In one mutant (Fig. 2, lane F) insertion was on the same EcoRI and Bam HI fragment, $2.3 \mathrm{~kb}$ apart. In the other (Fig. 2, lane B), two or four hybridization bands were found, indicating two insertions in the chromosome, which was rather unusual with $\operatorname{Tn} 917$. These latter insertions were on EcoRI or Bam $\mathrm{HI}$ fragments distinct from the previous 13.

\section{Isolation of insertions in 'essential' DNA regions of prophage BLF}

Two-thousand B. licheniformis 19 insertion mutants, isolated from 10 independent experiments, were tested for BLF phage production. Seven mutants $(0.35 \%)$ did not produce phage BLF spontaneously. The bacteria were prototrophic, produced $\mathrm{Bt}$ and showed the same phage sensitivity as the original triple lysogenic strain. To determine the transposon insertion sites, Southern hybridizations were performed with ${ }^{32} \mathrm{P}$-labelled pTnPF1 as probe. The transposon has two EcoRV cleavage sites, resulting in 0.4 (left end), 1.0 (middle) and $5.2 \mathrm{~kb}$ (right end) fragments. Thus, after EcoRV digestion, three fragments should hybridize with the PTnPF1 probe: an 
(a)

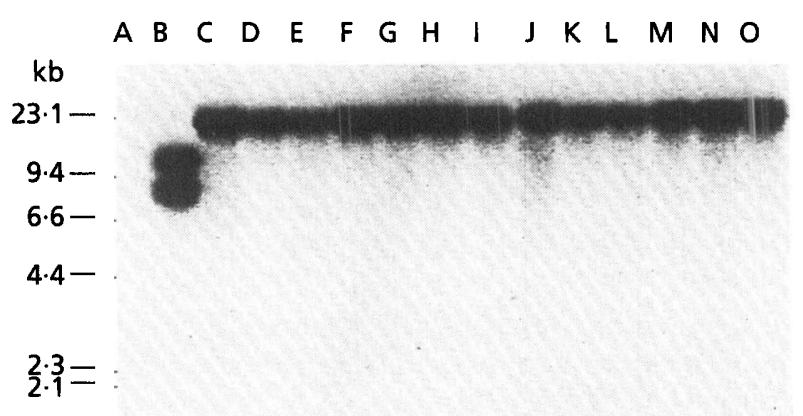

(c)

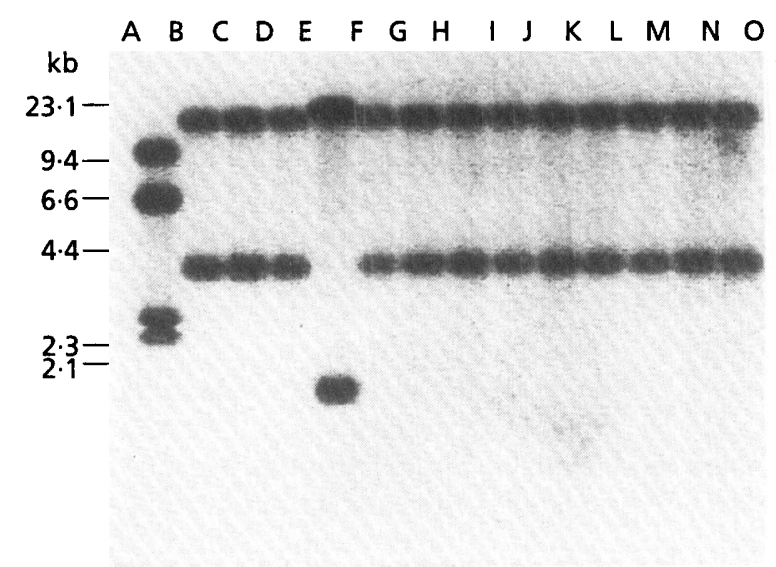

(b)

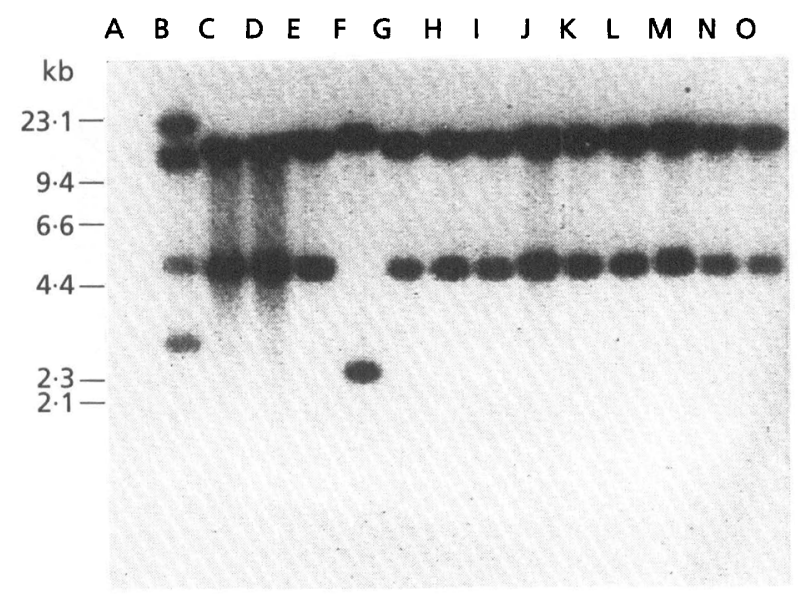

(d)

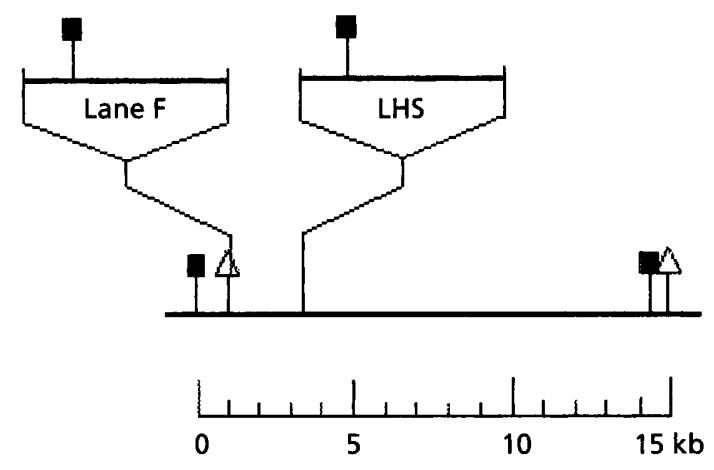

Fig. 2. Southern hybridizations of $B$. licheniformis ATCC 9800 sulphate reductase mutants containing Tn917PF1 insertions with 32P-labelled pTnPF1 DNA probe and the partial physical map of the sulphate reductase chromosomal region. The molecular mass marker was Hindlll-digested $\lambda$ DNA. The chromosomal DNA samples were digested by (a) EcoRI, (b) BamHI and (c) EcoRI and BamHI. Lanes: A, wild-type B. licheniformis ATCC 9800; B-O, B. licheniformis ATCC 9800 sulphate reductase auxotrophs. (d) Thirteen insertions were on the same EcoRI $(\triangle)$ and BamHI $(\square)$ fragment. One of them (Lane $F$ ) was $1.1 \mathrm{~kb}$ and the other 12 insertion sites (LHS, local hot spot) were $3.4 \mathrm{~kb}$ from the left-hand BamHI site. Transposon Tn917PF1 is indicated by a box.

identical middle and the two flanking parts attached to the chromosomal fragments of different sizes. It was seen that, after hybridization with the p'nPF1 probe (Fig. 3a), the mutants exhibited different hybridization patterns, supporting random transposon insertions. The presence of prophage BLF in the mutants was confirmed by hybridization with radiolabelled phage DNA (Fig. 3b).

\section{Isolation of Bt-non-producing mutants}

The same $2000 \mathrm{~B}$. licheniformis 19 insertion mutants were also tested for Bt production. No zone of inhibition was formed around 12 mutants $(0.6 \%)$ on the lawn of $M$. flavus. These $\mathrm{Bt}$ non-producers were prototrophic with the same phage sensitivity and phage production as the original strain.

To determine the sites of transposon insertions, the chromosomal DNAs of the 12 mutants were single- and double-digested with EcoRI, BamHI, Pst I and SmaI, separated by agarose gel electrophoresis and hybridized with radiolabelled transposon DNA. Accordingly, five different insertion sites could be distinguished (Fig. 4). Three representatives were on sites $C$ and $D$, four on site $\mathrm{E}$ and one on both $\mathrm{A}$ and $\mathrm{B}$. Based on the hybridization patterns, the partial physical map of the chromosomal region of the Bt synthetase gene was constructed (Fig. 5). Four insertion sites (A, B, C and D) were found on the same Pst or Bam HI fragment, while insertion site $\mathrm{E}$ was on another fragment. The beginning of the chromosomal part A-B-C-D overlapped the end of E. Therefore, the combined size of the two parts was about $47 \mathrm{~kb}$. In this region the order of the five insertion sites was E-A-B-C$D$, the distance between the outside insertions ( $E$ and $D$ ) was approximately $27 \cdot 4 \mathrm{~kb}$. 
(a)

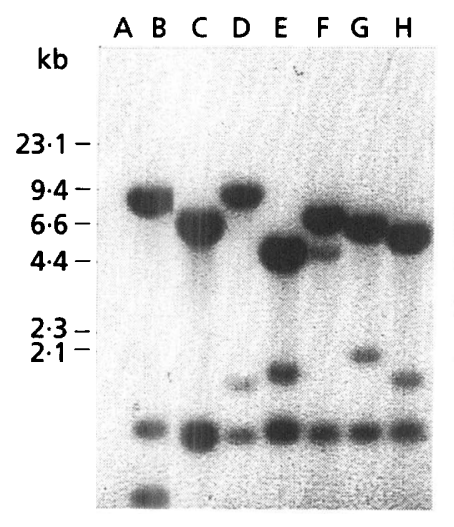

(b)
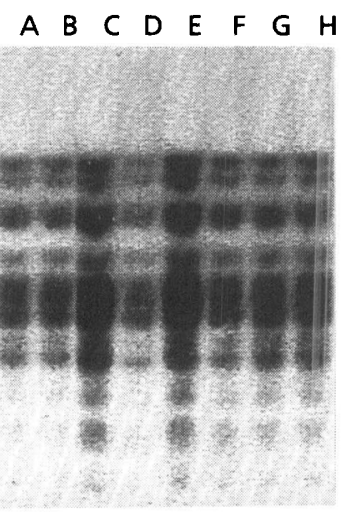

Fig. 3. DNA-DNA hybridization of EcoRV-digested $B$. licheniformis 19 chromosomal DNAs containing Tn917PF1 insertions, causing defective phage BLF phenotype. Probes were 32P-labelled pTnPF1 (a) and BLF DNA (b). The molecular mass marker was HindIII-digested $\lambda$ DNA. Lanes: $A$, wild-type $B$. licheniformis 19; B-H, B. licheniformis 19 insertion mutants carrying defective phage BLF. Only two bands were detected in lane $C$ of (a), because the left-flanking part of the transposon attached to the chromosomal fragment did not separate from the $1.0 \mathrm{~kb}$ middle transposon part with a simple electrophoresis (result not shown).

Although Tn917PF1 was constructed to drive the transcription of chromosomal genes by its strong outward $a p h A^{\prime}$ promoter (Zagorec \& Steinmetz, 1991), Btoverproducing mutants were not found among the 2000 insertions. About 10000 additional $B$. licheniformis 19 insertion mutants were tested for Bt production by replica plating. The Km-resistant colonies were tested with $M$. flavus. The inhibition zones were comparable with those of B. licheniformis 19, thus $\mathrm{Bt}$-overproducing mutants were not found.

\section{DISCUSSION}

Transposon $\operatorname{Tn} 917 P F 1$, a derivative of $\operatorname{Tn} 917$, was successfully introduced into $B$. licheniformis. Due to the temperature-sensitive replication of the plasmid vector pTnPF1, it was possible to eliminate the freely replicating plasmid from the transformed cell and transposon mutants could be isolated as reported by Zagorec \& Steinmetz (1991) for B. subtilis. For more efficient elimination of the vector, a higher temperature $\left(50^{\circ} \mathrm{C}\right)$ was used, as suggested by Wati et al. (1990) for B. licheniformis.

The frequency of Tn917PF1 transposition was nearly the same as that reported for B. subtilis (Zagorec \& Steinmetz, 1991) and B. licheniformis NCIB6346 (Wati et al., 1990). It was approximately tenfold higher than with the original Tn917 in B. subtilis (Youngman et al., 1983). In contrast to a reported case in Enterococcus faecalis (Tomich et al., 1980), Em was not needed to induce transposition in $B$. licheniformis.

The frequency of auxotrophic mutation was similar to that observed in B. megaterium (Bohall \& Vary, 1986) and B. amyloliquefaciens (Hartley \& Paddon, 1986), but was less than the 3-8\% in B. subtilis (Youngman et al., 1983) and $9 \%$ in B. licheniformis NCIB6346 (Wati et al., 1990). Based on the distribution of auxotrophs, no insertion 'hot spot' was found for transposon Tn917PF1 in the two $B$. licheniformis strains. This is in contrast with the hot spot regions observed in the glt locus in B. subtilis 168 (Youngman et al., 1983), and the $\arg G H$ region in $B$. licheniformis NCIB6346 (Wati et al., 1990). Nevertheless, strain ATCC 9800 should be identical to NCIB6346. An explanation of these different results could be that the results reported by Wati et al. (1990) were based on a few experiments in which early transpositions may have been enriched in the $\arg G H$ region. In the present work, 30 experiments were carried out with strain ATCC 9800 to decrease possible biased results. The distribution and phenotype of B. licheniformis 19 and ATCC 9800 auxotrophs were different (Table 1). This was not surprising, because the two strains are different in phage sensitivity and production, antibiotic sensitivity, Bt synthesis and colony morphology.

Considering the whole chromosome (Table 2 and Fig. 1) or larger DNA regions (Fig. 3) as potential targets for transposition, $\operatorname{Tn} 917 P F 1$ insertions occurred randomly, as observed in B. megaterium for Tn917 (Bohall \& Vary, 1986). However, smaller chromosomal regions, such as particular genes (Fig. 2 and Fig. 5), may have had a single or a few preferred target sites for transposon Tn917PF1. Thus, the Bt synthetase gene of at least $26 \mathrm{~kb}$ [estimated by the molecular mass of the three-component enzyme complex (Ishihara $e t$ al., 1989)] had three, and the smaller sulphate reductase gene had one target site in which more than one insertion was detected. It was interesting to observe that one of the sulphate reductase mutants had two chromosomal insertions, which is rather unusual for Tn917.

The partial physical map of the chromosomal region of the Bt synthetase gene (Fig. 5) was constructed based on hybridization patterns. Since the distance between the two outside insertions is about $27.4 \mathrm{~kb}$ and the estimated size of the Bt synthetase gene is at least $26 \mathrm{~kb}$, it is very likely that the three structural genes are located in an operon or a cluster. A similar arrangement was observed for other cyclic peptide antibiotics of Bacillus origin, like the synthetases of gramicidin S, tyrocidine and surfactin (Krätzschmar et al., 1989; Mittenhuber et al., 1989; Nakano et al., 1991). Clustering has also been observed for antibiotic biosynthesis of some Streptomyces and filamentous fungi (MacCabe et al., 1990; Malpartida et al., 1990; Gutiérrez et al., 1991; Raibaud et al., 1991; Tobin et al., 1991). Comparing this partial physical map with the physical map of $\mathrm{Bt}$ synthetase structural genes of $B$. licheniformis A TCC 10716 (Korsnes et al., 1986; Ishihara et al., 1989), there was little similarity. This may be explained by the difference in the two strains. B. licheniformis 19 was optimized for high industrial yield $\left(600-660 \mathrm{IU} \mathrm{Bt} \mathrm{ml}^{-1}\right)$, but ATCC 10716 is a low-yielding laboratory strain.

In about 12000 Tn917PF1 insertion mutants, Btoverproduction was not found. The explanation can be that either there was no preferred target site for the 
$\begin{array}{lllll}\text { BamHI } & \text { EcoRI } & \text { PstI } & \text { Bmal }\end{array}$

W A B C D E WA B C D E WA B C D E WA B C D E W W B C D E

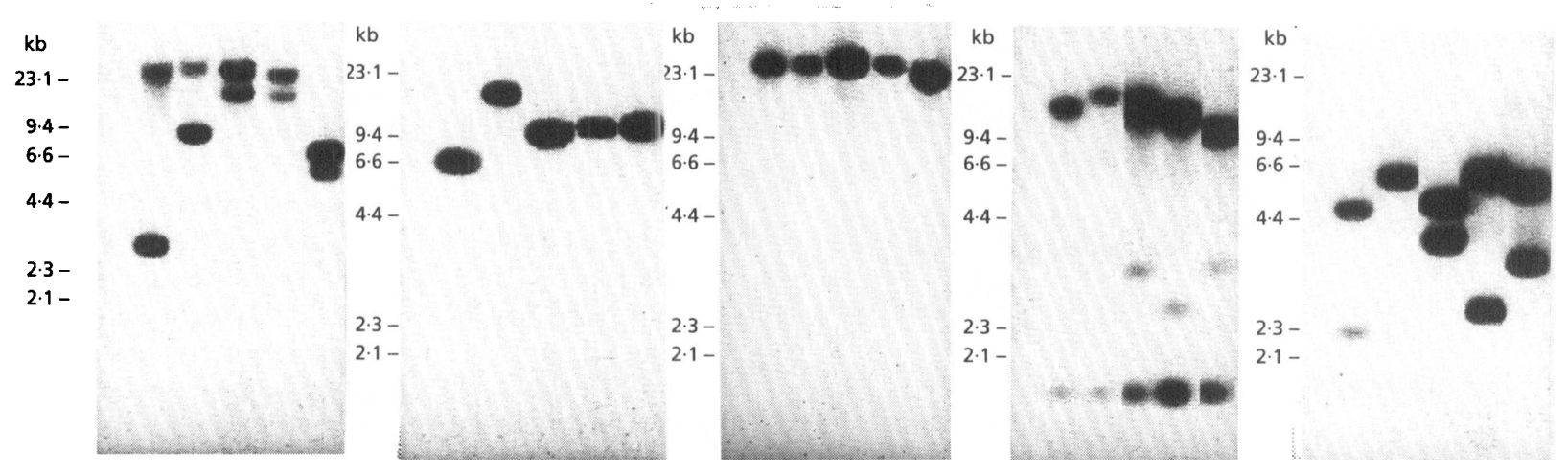

BamHI+Pstl

BamHl+Smal

ECORI+Pstl

ECoRl+Smal

Pstl+Smal

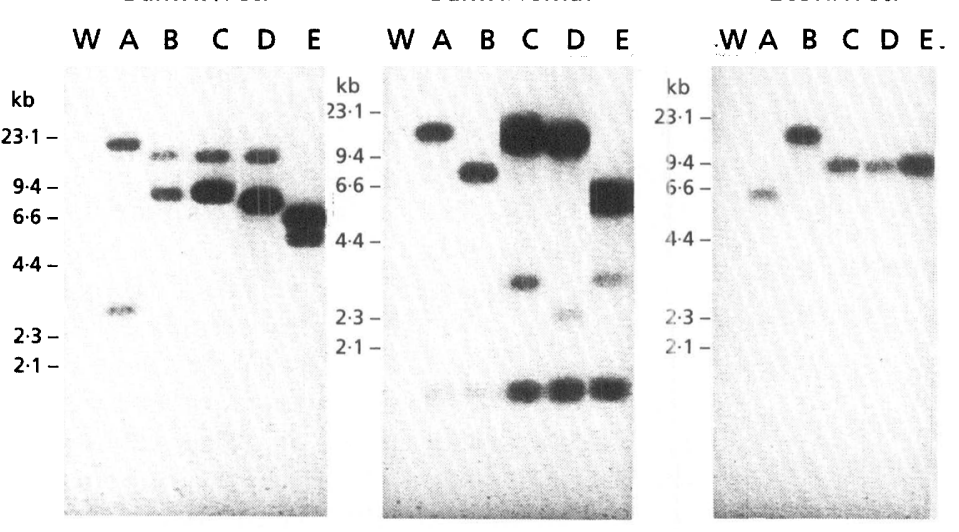

WA B C D E

W A B C D E

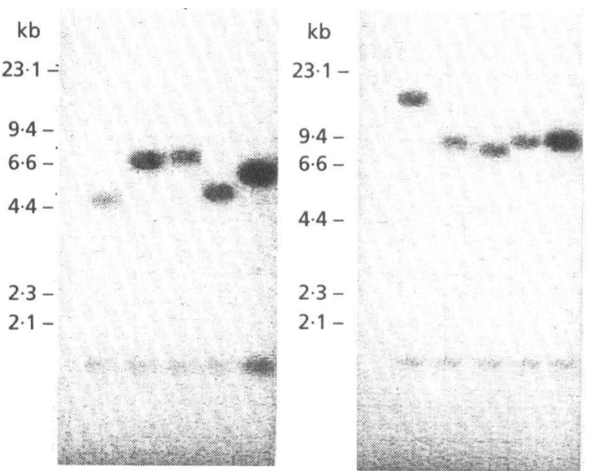

Fig. 4. DNA-DNA hybridization of five different $B$. licheniformis $19 \mathrm{Bt}$-non-producing Tn917PF1 mutants with ${ }^{32} \mathrm{P}$-labelled pTnPF1 as probe. The chromosomal DNAs were single- and double-digested with BamHI, EcoRI, Pstl and Smal. The molecular mass marker was HindIII-digested $\lambda$ DNA. Lanes: W, wild-type B. licheniformis 19; A-E, B. licheniformis 19 Btnon-producers. Tn917PF1 has no EcoRI or Pstl sites, but has one BamHI and two Smal sites as seen in Fig. 5. For single and double Smal digestions, too little chromosomal DNA was used in some lanes, so the third band, the transposon leftflanking part $(0.3 \mathrm{~kb})$ with a chromosomal fragment, could not be detected.
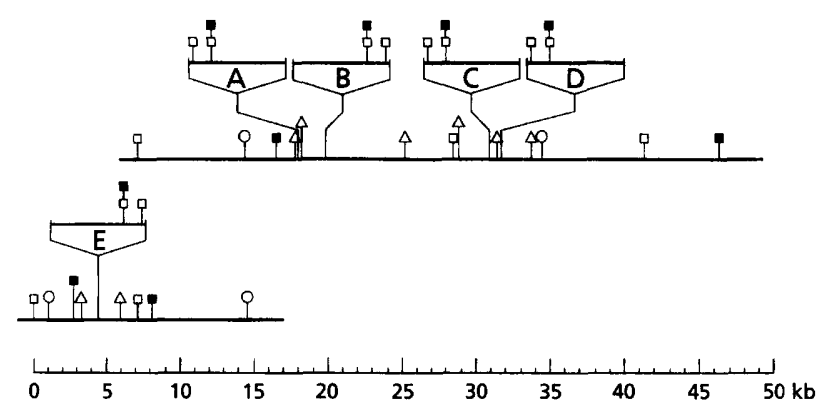

Fig. 5. Tn917PF1 insertions in the Bt synthetase gene. The chromosome is indicated by a horizontal line with restriction endonuclease cleavage sites $(\square, B a m H I ; \triangle$, EcoRl; $O$, Pstl; $\square$, Smal). Tn917PF1 is indicated by a box. The partial restriction map was constructed on the basis of Fig. 4. Insertion sites were marked A, B, C, D and E according to the lanes in Fig. 4.

transposon in the regulator region of Bt synthetase gene, or the transposon was inserted in the wrong orientation. Even if inserted in the right orientation, no overpro- duction can be expected when the aph $A^{\prime}$ promoter is weaker than that of the $\mathrm{Bt}$ synthetase gene.

\section{ACKNOWLEDGEMENTS}

We are grateful to Michel Steinmetz for the generous gifts of $B$. subtilis GM479 (pTnPF1 donor). We would like to thank Lóránd Szabó for carrying out some of the tests, László Szabó, $\mathrm{ABC}$, for taking video photographs and Mark Davies for his help in revising the manuscript. The work was supported by the Foundation for Hungarian Higher Education and Research grant No. 1019/92.

\section{REFERENCES}

Bohall, N. A. \& Vary, P. S. (1986). Transposition of Tn917 in Bacillus megaterium. J Bacteriol 167, 716-718.

Bron, S. (1990). Plasmids. In Molecular Biological Methods for Bacillus, pp. 75-174. Edited by C. R. Harwood \& S. M. Cutting. Chichester: John Wiley.

Doskočil, J., Forstová, J. \& Štorchová, H. (1986). Physical mapping of LP51 and LP52 prophages of lysogenic strains of Bacillus licheniformis. Mol \& Gen Genet 205, 530-534. 
Gutiérrez, S., Díez, B., Montenegro, E. \& Martín, J. F. (1991). Characterization of the Cephalosporium acremonium $p c b A B$ gene encoding $\alpha$-aminoadipyl-cysteinyl-valine synthetase, a large multidomain peptide synthetase: linkage to the $p c b C$ gene as a cluster of early cephalosporin biosynthetic genes and evidence of multiple functional domains. J Bacteriol 173, 2354-2365.

Hanlon, G. W. \& Hodges, N. A. (1981). Bacitracin and protease production in relation to sporulation during exponential growth of Bacillus licheniformis on poorly utilized carbon and nitrogen sources. $J$ Bacteriol 147, 427-431.

Hartley, R. W. \& Paddon, C. J. (1986). Use of plasmid PTV1 in transposon mutagenesis and gene cloning in Bacillus amyloliquefaciens. Plasmid 16, 45-51.

Holczinger, A. (1986). Improvement of bacitracin production and bacteriophages of Bacillus licheniformis. $\mathrm{PhD}$ Thesis, Budapest Technical Lniversity.

Holliday, R. (1956). A new method for the identification of biochemical mutants of microorganisms. Nature 178, 987.

Ishihara, H., Hara, N. \& Iwabuchi, T. (1989). Molecular cloning and expression in Escherichia coli of the Bacillus licheniformis bacitracin synthetase 2 gene. $J$ Bacteriol 171, 1705-1711.

Korsnes, L., Gulliksen, O.-M., Sundan, A. \& Nerland, A. (1986). Cloning of genes from Bacillus licheniformis involved in synthesis of the peptide antibiotic bacitracin. In Bacillus Molecular Genetics and Biotechnology Applications, pp. 283-294. Edited by A. T. Ganesan \& J. A. Hoch. Orlando: Academic Press.

Krätzschmar, J., Krause, M. \& Marahiel, M. A. (1989). Gramicidin $\mathrm{S}$ biosynthesis operon containing the structural genes grs $A$ and $g r s B$ has an open reading frame encoding a protein homologous to fatty acid thioesterases. J Bacteriol 171, 5422-5429.

MacCabe, A. P., Riach, M. B. R., Unkles, S. E. \& Kinghorn, J. R. (1990). The Aspergillus nidulans npe $A$ locus consists of three contiguous genes required for penicillin biosynthesis. EMBO J 9 , 279-287.

Malpartida, F., Niemi, J., Navarrete, R. \& Hopwood, D. A. (1990). Cloning and expression in a heterologous host of the complete set of genes for biosynthesis of the Streptomyces coelicolor antibiotic undecylprodigiosin. Gene 93, 91-99.

Mittenhuber, G., Weckermann, R. \& Marahiel, M. A. (1989). Gene cluster containing the genes for tyrocidine synthetases 1 and 2 from Bacillus brevis: evidence for an operon. J Bacteriol 171, 4881-4887.

Nakano, M. M., Magnuson, R., Myers, A., Curry, J., Grossman, A. D. \& Zuber, P. (1991). $\operatorname{srf} A$ is an operon required for surfactin production, competence development, and efficient sporulation in Bacillus subtilis. J Bacteriol 173, 1770-1778.

Perbal, B. (1988). A Practical Guide to Molecular Cloning, 2nd edn. New York: John Wiley.

Perkins, J. B. \& Youngman, P. J. (1986). Construction and properties of Tn917-lac, a transposon derivative that mediates transcriptional gene fusions in Bacillus subtilis. Proc Natl Acad Sci US A 83, $140-144$.

Prágai, 2., Holczinger, A. \& Sik, T. (1994). Transformation of Bacillus licheniformis protoplasts by plasmid DNA. Microbiology 140, 305-310.

Raibaud, A., Zalacain, M., Holt, T. G., Tizard, R. \& Thompson, C. J.
(1991). Nucleotide sequence analysis reveals linked $N$-acetyl hydrolase, thioesterase, transport, and regulatory genes encoded by the bialaphos biosynthetic gene cluster of Streptomyces bygroscopicus. $J$ Bacteriol 173, 4454-4463.

Sambrook, J., Fritsch, E. F. \& Maniatis, T. (1989). Molecular Cloning: a Laboratory Manual, 2nd edn. Cold Spring Harbor, NY: Cold Spring Harbor Laboratory.

Sandman, K., Losick, R. \& Youngman, P. (1987). Genetic analysis of Bacillus subtilis spo mutations generated by Tn917-mediated insertional mutagenesis. Genetics 117, 603-617.

Sík, T., Horváth, J. \& Chatterjee, S. (1980). Generalized transduction in Rbizobium meliloti. Mol \& Gen Genet 178, 511-516.

Thorne, C. B. \& Kowalski, J. B. (1976). Temperate bacteriophages for Bacillus licheniformis. In Microbiology 1976, pp. 303-314. Edited by D. Schlessinger. Washington, DC: American Society for Microbiology.

Tobin, M. B., Kovacevic, S., Madduri, K., Hoskins, J. A., Skatrud, P. L., Vining, L. C., Stuttard, C. \& Miller, J. R. (1991). Localization of the lysine $\varepsilon$-aminotransferase (lat) and $\delta$-(L- $\alpha$-aminoadipyl)-Lcysteinyl-D-valine synthetase $(p c b A B)$ genes from Streptomyces clavuligerus and production of lysine $\varepsilon$-aminotransferase activity in Eschericbia coli. J Bacteriol 173, 6223-6229.

Tomich, P. K., An, F. Y. \& Clewell, D. B. (1980). Properties of erythromycin-inducible transposon Tn 917 in Streptococcus faecalis. $J$ Bacteriol 141, 1366-1374.

Vandeyar, M. A. \& Zahler, S. A. (1986). Chromosomal insertions of Tn917 in Bacillus subtilis. J Bacteriol 167, 530-534.

Wati, M. R., Priest, F. G. \& Mitchell, W. J. (1990). Mutagenesis using Tn917 in Bacillus licheniformis. FEMS Microbiol Lett 71, 211-214.

Youngman, P. (1987). Plasmid vectors for recovering and exploiting Tn917 transpositions in Bacillus and other Gram-positive bacteria. In Plasmids: a Practical Approach, pp. 79-103. Edited by K. Hardy. Oxford: IRL Press.

Youngman, P. (1990). Use of transposons and integrational vectors for mutagenesis and construction of gene fusions in Bacillus species. In Molecular Biological Methods for Bacillus, pp. 221-266. Edited by C. R. Harwood \& S. M. Cutting. Chichester: John Wiley.

Youngman, P. J., Perkins, J. B. \& Losick, R. (1983). Genetic transposition and insertional mutagenesis in Bacillus subtilis with Streptococcus faecalis transposon Tn917. Proc Natl Acad Sci US A 80, 2305-2309.

Youngman, P., Perkins, J. B. \& Losick, R. (1984). A novel method for the rapid cloning in Escherichia coli of Bacillus subtilis chromosomal DNA adjacent to Tn 917 insertions. Mol \& Gen Genet 195 , 424-433.

Zagorec, M. \& Steinmetz, M. (1991). Construction of a derivative of $\operatorname{Tn} 917$ containing an outward-directed promoter and its use in Bacillus subtilis. J Gen Microbiol 137, 107-112.

Zuberi, A. R., Ying, C., Parker, H. M. \& Ordal, G. W. (1990). Transposon Tn917lac $Z$ mutagenesis of Bacillus subtilis: identification of two new loci required for motility and chemotaxis. J Bacteriol 172, 6841-6848.

Received 11 May 1994; revised 14 July 1994; accepted 20 July 1994. 